\title{
CHARACTERIZATION OF AN INORGANIC-ORGANIC HYBRID POLYOXOMOLYBDATE $\left(\mathrm{C}_{6} \mathrm{H}_{18} \mathrm{~N}_{2}\right)_{2}\left[\mathrm{H}_{2} \mathrm{Mo}_{7} \mathrm{O}_{24}\right] \cdot 7 \mathrm{H}_{2} \mathrm{O}$
}

\begin{abstract}
M.M. Ftini
Laboratoire de matériaux et cristallochimie (LMC), Département de chimie, Faculté des sciences Monastir, Tunisie E-mail: mohamedmongi@yahoo.fr

Received September, 7, 2014

A novel inorganic-organic hybrid salt, hexanediammonium heptamolybdate $\left(\mathrm{C}_{6} \mathrm{H}_{18} \mathrm{~N}_{2}\right)_{2}\left[\mathrm{H}_{2} \mathrm{Mo}_{7} \mathrm{O}_{24}\right] \cdot 7 \mathrm{H}_{2} \mathrm{O}$ has been synthesized and characterized by elemental analyses, IR, TGA, cyclic voltammetry, UV and X-ray single crystal diffraction. It crystallizes in triclinic space group $P-1$ with $a=10.0619(2) \AA, b=12.059(2) \AA, c=20.044(3) \AA, \alpha=97.06(1)^{\circ}$, $\beta=91.56(1)^{\circ}, \gamma=110.59(2)^{\circ}$ and $Z=2$. The crystal structure shows that seven $\mathrm{MoO}_{6}$ distorted octahedra share edges which have four ranges of $\mathrm{Mo}-\mathrm{O}$ bond distances. The heptamolybdate anion of the crystal has approximate $\mathrm{mm} 2$ point symmetry and its structure is similar to that observed in other heptamolybdates. The titled compound consists of the protonated hexanediamine cations and the inorganic $\left[\mathrm{H}_{2} \mathrm{Mo}_{7} \mathrm{O}_{24}\right]^{4-}$ oxomolybdate anions, linked by hydrogenbonding interactions.
\end{abstract}

DOI: $10.15372 / \mathrm{JSC} 20150821$

K e y w o r d s: synthesis, polyoxometalate, organic-inorganic hybrid solids, cyclic voltammetry, UV visible spectrum.

\section{INTRODUCTION}

Polyoxometalates (POMs), are considered as important inorganic building blocks for the construction of supramolecular compounds. They have attracted considerable research interest in recent years because of the potential applications in diverse areas, such as biomedical chemistry, catalysis, magnetism, sorption, etc. [ $1-4]$. One of the recent advances in POMs chemistry is prepation of a large number of POMs-based organic and inorganic hybrid materials having well-defined channels and cavities, which are important for materials chemistry [5-8].

In polyoxomolybdate chemistry, a wide variety of compounds, clusters and solid-state structures have been reported, but understanding the driving force for the formation of these high-nuclearity species is still a formidable challenge. Based on the self-assembly point of view, assumptions such as reduction-oxidation-reconstitution [9] and polymerization-reduction [10] have been presented, suggesting a two-step process: first, raw materials react with each other to give various building blocks; second, these building blocks assemble automatically under suitable conditions to form products. According to these assumptions, a few types of building blocks can be identified from a large number of polyoxomolybdates, and the same building block will prove to have various assembly types and produce various solid materials with 1D chain, 2D layer or 3D cationic framework structures [11-13 ]. A possible route to synthesize POM-supported transition metal complexes is to use organic amine cations (protonated amines) that stabilize the POM cluster anion with the assistance of supramolecular noncovalent interactions [14-18]. Several heptamolybdates that are charge balanced by inorganic 
Crystal data and structure refinement for the compound $\left(\mathrm{C}_{6} \mathrm{H}_{18} \mathrm{~N}_{2}\right)_{2}\left[\mathrm{H}_{2} \mathrm{Mo}_{7} \mathrm{O}_{24}\right] \cdot 7 \mathrm{H}_{2} \mathrm{O}$

\begin{tabular}{|c|c|}
\hline Empirical formula & $\left(\mathrm{C}_{6} \mathrm{~N}_{2} \mathrm{H}_{18}\right)_{2}\left[\mathrm{H}_{2} \mathrm{Mo}_{7} \mathrm{O}_{24}\right] \cdot 7 \mathrm{H}_{2} \mathrm{O}$ \\
\hline Formula weight & 1420.16 \\
\hline Crystal system; space group & Triclinic; $P-1$ \\
\hline Cell parameters: $a, b, c, \AA$ & $10.062(2), 12.059(2), 20.044(3)$ \\
\hline$\alpha, \beta, \gamma$, deg. & $97.06(1), 91.56(1), 110.59(2)$ \\
\hline$Z ; V, \AA^{3}$ & $2 ; 2252.9(7)$ \\
\hline$D_{\mathrm{c}}, \mathrm{g} / \mathrm{cm}^{3}$ & 2.093 \\
\hline Temperture, $\mathrm{K}$ & 293(2) \\
\hline Diffractomerter & Enraf-Nonius CAD4 \\
\hline Monochromator & Graphite \\
\hline Radiation & $\operatorname{Mo} K_{\alpha}(\lambda=0.71073 \AA)$ \\
\hline$h k l$ range & $-11 \leq h \leq-1,-13 \leq k \leq 14,-23 \leq l \leq 23$ \\
\hline$\theta$ limit, deg. & $2.17-24.97$ \\
\hline Reflections collected / independent / observed & $7944 / 7381 / 5333$ \\
\hline Number of parameters & 490 \\
\hline Goodness of fit & 1.021 \\
\hline$R_{1} / w R_{2}(\mathrm{obs})$ & $0.0606 / 0.1662$ \\
\hline Weighting scheme & $\begin{array}{c}w=1 /\left[\sigma^{2}\left(\left|F_{0}\right|^{2}\right)+(0.0835 P)^{2}+18.1685 P\right] \\
\text { where } P=\left(\left|F_{0}\right|^{2}+2\left|F_{\mathrm{c}}\right|^{2}\right) / 3\end{array}$ \\
\hline
\end{tabular}

counter ions have been synthesized and structurally characterized [19-31 ]. By using protonated hexanediamine as counter ions, we have successfully synthesized a new hybrid organic-inorganic compound in which hydrogen bonding of conventional $\mathrm{O}-\mathrm{H} \ldots \mathrm{O}$ and $\mathrm{N}-\mathrm{H} . . \mathrm{O}$ motifs has been the most commonly connection style between organic and inorganic molecular fragments.

\section{EXPERIMENTAL SECTION}

Synthesis. The compound $\left(\mathrm{C}_{6} \mathrm{H}_{18} \mathrm{~N}_{2}\right)_{2}\left[\mathrm{H}_{2} \mathrm{Mo}_{7} \mathrm{O}_{24}\right] \cdot 7 \mathrm{H}_{2} \mathrm{O}$ is prepared from using an aqueous solution of hexanediamine (1.4 mL dissolved in $20 \mathrm{~mL}$ of water) added slowly to a solution of ammonium molybdate $\left(\mathrm{NH}_{4}\right)_{6}\left[\mathrm{Mo}_{7} \mathrm{O}_{24}\right] \cdot 4 \mathrm{H}_{2} \mathrm{O}(3.52 \mathrm{~g}$ in $100 \mathrm{~mL}$ of water). The resulting mixture was stirred for 3 hours. The solution was kept for 20 days at ambient conditions, and then colorless block crystals suitable for X-ray crystallography were obtained.

The semi-quantitative energy-dispersive spectroscopy (EDS) analysis of one of the colorless crystals revealed the presence of $\mathrm{Mo}, \mathrm{C}, \mathrm{N}$ and $\mathrm{O}$.

Single-crystal X-ray diffraction. The structure was solved by direct methods using the program SHELXS-97 [32 ] and refined by full-matrix least-squares based on $F^{2}$ with the program SHELXL-97 [33 ] included in the WINGX software package [34]. The crystal data and structure refinement are summarized in Table 1. All non-hydrogen atoms were refined, first with isotropic and finally anisotropic thermal displacement parameters. Hydrogen atoms were introduced at calculated positions and included in the final refinement.

\section{RESULTS AND DISCUSSION}

Crystal structures. $\mathrm{X}$-ray structural analysis reveals that a single crystal of the compound $\left(\mathrm{C}_{6} \mathrm{H}_{18} \mathrm{~N}_{2}\right)_{2}\left[\mathrm{H}_{2} \mathrm{Mo}_{7} \mathrm{O}_{24}\right] \cdot 7 \mathrm{H}_{2} \mathrm{O}$, is made up of a heptamolybdate anion, two protonated hexandiamine cations and seven lattice water molecules. The $\left[\mathrm{Mo}_{7} \mathrm{O}_{24}\right]^{6-}$ anion is made up of seven distorted edgesharing $\mathrm{MoO}_{6}$ octahedra (Fig. 1). Due to the different coordination modes of oxygen atoms in the 
Fig. 1. A view of the $\left[\mathrm{H}_{2} \mathrm{Mo}_{7} \mathrm{O}_{24}\right]^{4-}$ anion with the atomic numbering scheme

polyanion units, the Mo-O bond lengths can be classified into four categories: $\mathrm{Mo}-\mathrm{O}_{\mathrm{t}}\left(\mathrm{O}_{\mathrm{t}}\right.$ : the terminal oxygen $(\mathrm{O}(12)$, $\mathrm{O}(19), \mathrm{O}(21), \mathrm{O}(7), \mathrm{O}(18), \mathrm{O}(22), \mathrm{O}(14)$, $\mathrm{O}(24), \quad \mathrm{O}(23), \quad \mathrm{O}(16), \quad \mathrm{O}(20), \quad \mathrm{O}(5)))$, 1.709(8)-1.741(8) Аं; Mo-O2 (O2: twofold-coordinated oxygen $(\mathrm{O}(4), \mathrm{O}(8), \mathrm{O}(9)$, $\mathrm{O}(10), \quad \mathrm{O}(11), \quad \mathrm{O}(13), \quad \mathrm{O}(15), \quad \mathrm{O}(17)))$, 1.732(7)-2.503(7) $\AA$; Mo-O3 (O3: threefold-coordinated oxygen $(\mathrm{O}(3), \mathrm{O}(6)))$, 1.885(7)-2.285(7) А; Mo-O4 (O4: fourfold-coordinated oxygen $(\mathrm{O}(1), \mathrm{O}(2)))$ 2.158(7)-2.272(7) $\AA$. Nevertheless, the

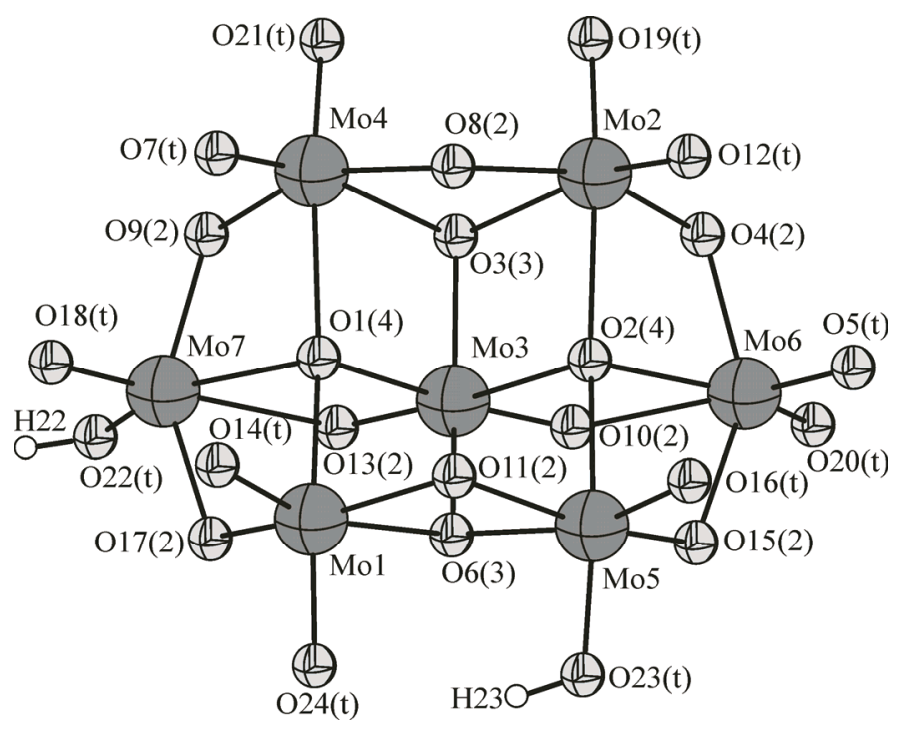
$\mathrm{Mo}(3)-\mathrm{O}(10)$ and $\mathrm{Mo}(3)-\mathrm{O}(13)$ distances are more typical of terminal oxygen bond lengths $(1.739(8) \AA$ and $1.732(7) \AA)$ than the twofoldcoordinated oxygen. Table 2 present selected bond distances for the title compound. All Mo centers have two terminal oxygen atoms except $\mathrm{Mo}(3)$ which locates in the cavity of the bowl-shaped $\left[\mathrm{Mo}_{7} \mathrm{O}_{24}\right]^{6-}$ cluster.

T a b l e 2

Selected bond lengths and hydrogen-bonding parameters $(\AA)$ for the compound $\left(\mathrm{C}_{6} \mathrm{H}_{18} \mathrm{~N}_{2}\right)_{2}\left[\mathrm{H}_{2} \mathrm{Mo}_{7} \mathrm{O}_{24}\right] \cdot 7 \mathrm{H}_{2} \mathrm{O}$

\begin{tabular}{|c|c|c|c|c|c|}
\hline Bonds & Distances & Bonds & Distances & $\mathrm{D}-\mathrm{H} \ldots \mathrm{A}$ & $d(\mathrm{D} \ldots \mathrm{A})$ \\
\hline $\mathrm{Mo} 1-\mathrm{O} 24$ & $1.719(8)$ & $\mathrm{Mo} 2-\mathrm{O} 12$ & $1.721(9)$ & N1-H1A...OW4 & 2.820 \\
\hline Mo1-O14 & $1.725(9)$ & Mo2-O19 & $1.728(8)$ & $\mathrm{N} 1-\mathrm{H} 1 \mathrm{~B} \ldots \mathrm{O} 16$ & 2.771 \\
\hline Mo1-O11 & $1.927(7)$ & $\mathrm{Mo} 2-\mathrm{O} 8$ & $1.936(8)$ & N2-H2A...OW3 & 2.837 \\
\hline Mo1-O17 & $1.969(8)$ & $\mathrm{Mo} 2-\mathrm{O} 4$ & $1.993(8)$ & $\mathrm{N} 2-\mathrm{H} 2 \mathrm{~B} \ldots \mathrm{OW} 1$ & 2.794 \\
\hline Mo1-O1 & $2.189(7)$ & $\mathrm{Mo} 2-\mathrm{O} 2$ & $2.165(7)$ & $\mathrm{N} 2-\mathrm{H} 2 \mathrm{C} \ldots \mathrm{O} 5$ & 2.919 \\
\hline Mo1-O6 & $2.286(8)$ & $\mathrm{Mo} 2-\mathrm{O} 3$ & $2.262(7)$ & N3-H3A...O15 & 2.920 \\
\hline Mo3-O13 & $1.731(8)$ & $\mathrm{Mo} 4-\mathrm{O} 7$ & $1.710(9)$ & N3-H3B...O24 & 2.822 \\
\hline Mo3-O10 & $1.739(8)$ & $\mathrm{Mo} 4-\mathrm{O} 21$ & $1.727(9)$ & N3-H3C...OW1 & 3.077 \\
\hline Mo3-O6 & $1.885(7)$ & Mo4-O8 & $1.947(8)$ & N4-H4A...O3 & 2.748 \\
\hline $\mathrm{Mo3}-\mathrm{O} 3$ & & Mo4-O9 & $1.994(8)$ & N4-H4B...O19 & 2.990 \\
\hline $\mathrm{Mo} 3-\mathrm{O} 2$ & $2.267(7)$ & Mo4-O1 & $2.156(7)$ & N4-H4C...O21 & 2.904 \\
\hline Mo3-O1 & $2.270(8)$ & $\mathrm{Mo} 4-\mathrm{O} 3$ & $2.279(8)$ & $\mathrm{OW} 1-\mathrm{H} 1 \mathrm{~W} 1 \ldots \mathrm{O} 23$ & 2.736 \\
\hline Mo5-O16 & $1.713(8)$ & Mo6-O5 & $1.710(8)$ & $\mathrm{OW} 2-\mathrm{H} 1 \mathrm{~W} 2 \ldots \mathrm{O} 11$ & 2.779 \\
\hline Mo5-O23 & $1.728(8)$ & Mo6-O20 & $1.721(9)$ & $\mathrm{OW} 2-\mathrm{H} 2 \mathrm{~W} 2 \ldots \mathrm{O} 8$ & 2.746 \\
\hline Mo5-O11 & $1.936(8)$ & Mo6-O15 & $1.922(8)$ & OW3-H1W3...OW2 & 2.809 \\
\hline Mo5-O15 & $1.983(8)$ & Mo6-O4 & $1.940(8)$ & OW3-H2W3 ...O13 & 2.839 \\
\hline $\mathrm{Mo5}-\mathrm{O} 2$ & $2.208(7)$ & Mo6-O2 & $2.170(7)$ & OW5-H2W5 ..O22 & 2.822 \\
\hline Mo5-O6 & $2.246(7)$ & Mo6-O10 & $2.503(8)$ & OW6-H1W6...O14 & 2.989 \\
\hline Mo7-O18 & $1.724(9)$ & Mo7-O17 & $1.924(8)$ & OW6-H2W6...OW5 & 2.884 \\
\hline Mo7-O22 & $1.745(9)$ & Mo7-O1 & $2.172(7)$ & OW7-H1W7...O4 & 2.726 \\
\hline Mo7-O9 & $1.913(8)$ & Mo7-O13 & $2.493(9)$ & & \\
\hline
\end{tabular}

$\mathrm{D}=$ donor, $\mathrm{A}=$ acceptor. 


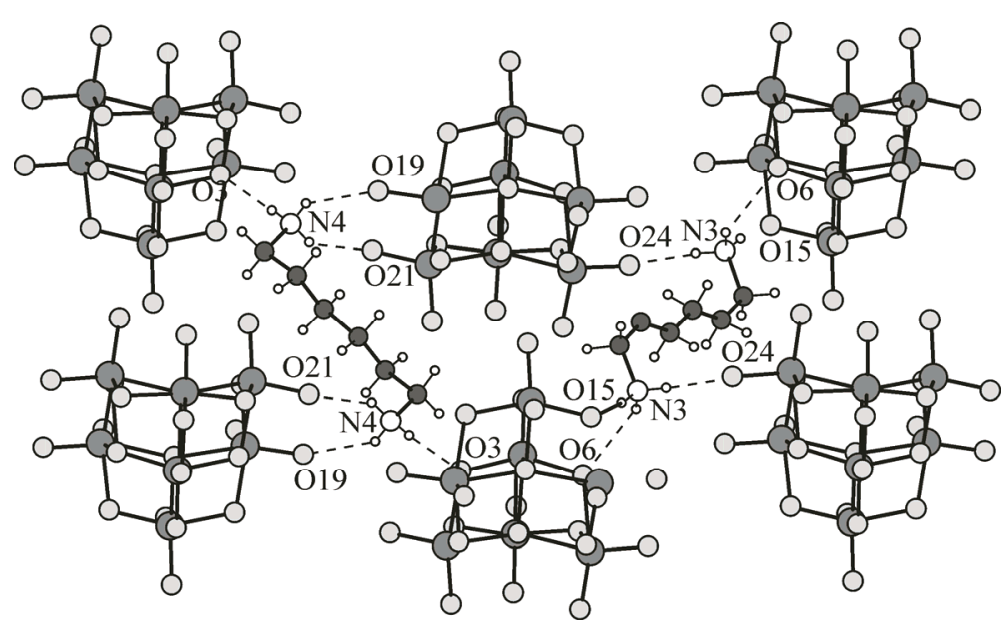

Fig. 2. A view of the layer forming the framework of $\left(\mathrm{C}_{6} \mathrm{H}_{18} \mathrm{~N}_{2}\right)_{2}\left[\mathrm{H}_{2} \mathrm{Mo}_{7} \mathrm{O}_{24}\right]$. . $7 \mathrm{H}_{2} \mathrm{O}$ compound showing the hydrogen bonding interactions between protonated hexanediamine and $\left[\mathrm{H}_{2} \mathrm{Mo}_{7} \mathrm{O}_{24}\right]^{4-}$ polyanions. All lattice water molecules are omitted for clarity

The hydrogen atoms $\mathrm{H}(22)$ and $H(23)$ are located from a difference Fourier map, and bonds lengths $\mathrm{Mo}(5)-\mathrm{O}(23)$ and $\mathrm{Mo}(7)-\mathrm{O}(22)$ are longer $(1.727 \AA$ and $1.741 \AA)$ than those of the $\mathrm{Mo}-\mathrm{O}_{\mathrm{t}}$ bonds which range from $1.709 \AA$ to $1.726 \AA$. Bond valence sum calculations (BVS) [35] indicate that the oxygen atoms $\mathrm{O}(22)$ and $\mathrm{O}(23)$ are protonated. The same location of a hydrogen atom at a terminal oxygen atom was proposed in the structure of $\mathrm{Cs}_{5} \mathrm{Mo}_{8} \mathrm{O}_{24}(\mathrm{OH})_{2} \mathrm{AsO}_{4} \cdot 2 \mathrm{H}_{2} \mathrm{O}$ [36 ], and location at the triply bonded oxygen atom was proposed in the papers describing the structures of tetrakis $(n$-hexylammonium)dihydrogendecavanadate [37 ], $\left[\left(\mathrm{CH}_{3}\right)_{4} \mathrm{~N}\right]_{4}\left[\mathrm{H}_{2} \mathrm{MoV}_{9} \mathrm{O}_{28}\right] \mathrm{Cl} \cdot 6 \mathrm{H}_{2} \mathrm{O}$ [38 ] and $\left(\mathrm{H}_{2} \text { pip }\right)_{3} \times$ $\times\left[\mathrm{Co}_{3} \mathrm{Mo}_{12} \mathrm{O}_{24}(\mathrm{OH})_{6}\left(\mathrm{PO}_{4}\right)_{8}\left(\mathrm{H}_{1.5} \mathrm{pip}\right)_{4}\right] \cdot 5 \mathrm{H}_{2} \mathrm{O}$ [39] , and in the structure of tetrakis-adenosinium dihydrogendecavanadate undecahydrate such protonation was assigned to the doubly-bridging oxygen atoms [ 40$]$. In the structure of the title compound, $\left[\mathrm{H}_{2} \mathrm{Mo}_{7} \mathrm{O}_{24}\right]^{4}$ anions connect to each other by a complex network of hydrogen-bonding interactions (Table 2). The protonated amine $\left[\mathrm{H}_{3} \mathrm{~N}-\left(\mathrm{CH}_{2}\right)_{6}-\right.$ $\left.\mathrm{NH}_{3}\right]^{2+}$ is not only a component for charge compensation, but also building brick located between $\left[\mathrm{H}_{2} \mathrm{Mo}_{7} \mathrm{O}_{24}\right]^{4-}$ polyanions, connected to the oxygen atoms of the heptamolybdate. The three-dimensional network is constructed from the association of layers parallel to the $a c$ plane, these layers are made up by the $\left[\mathrm{H}_{2} \mathrm{Mo}_{7} \mathrm{O}_{24}\right]^{4-}$ anions, and the organic cations which are linked together via $\mathrm{N}-\mathrm{H} \ldots \mathrm{O}$ hydrogen bonds (Fig. 2). The organic cation links four polyanions by sharing of adjacent oxygen atoms, the $-\mathrm{N}(3) \mathrm{H}_{3}^{+}$moiety is surrounded by two polyanions, and it makes two hydrogen bonds with the first polyanion by sharing two twofold-coordinated oxygen atoms $\mathrm{O}(15)$ and $\mathrm{O}(6)$, and one hydrogen bond with the second one by sharing a terminal oxygen atom $\mathrm{O}(24)$. The hydrogen bonds distances are $2.048 \AA, 2.446 \AA$ and $1.950 \AA$ for $\mathrm{N}(3)-\mathrm{H}(3 \mathrm{~A}) \ldots \mathrm{O}(15), \mathrm{N}(3)-\mathrm{H}(3 \mathrm{~A}) \ldots \mathrm{O}(6)$, and $\mathrm{N}(3)-\mathrm{H}(3 \mathrm{~B}) \ldots \mathrm{O}(24)$, respectively. The second $-\mathrm{N}(4) \mathrm{H}_{3}^{+}$moiety has also three bonding interactions with two neighboring $\left[\mathrm{H}_{2} \mathrm{Mo}_{7} \mathrm{O}_{24}\right]^{4-}$ polyanions by sharing two terminal oxygens $\mathrm{O}(19)$ and $\mathrm{O}(21)$ from the first polyanion, and one threefold coordinated oxygen atom $\mathrm{O}(3)$ from another polyanion. These hydrogen bonds are $\mathrm{N}(4)-\mathrm{H}(4 \mathrm{~B}) \ldots \mathrm{O}(19), \mathrm{N}(4)-\mathrm{H}(4 \mathrm{C}) \ldots \mathrm{O}(21)$, and $\mathrm{N}(4)-\mathrm{H} 4 \mathrm{~A}) \ldots \mathrm{O}(3)$ with bond length $2.257 \AA, 2.105 \AA$, and $1.913 \AA$, respectively.

Fig. 3 shows the connection mode between successive layers, the organic molecule donaits $\mathrm{N}-\mathrm{H}$ bonds to form $\mathrm{N}-\mathrm{H}$...O hydrogen bonds with two surrounding $\left[\mathrm{H}_{2} \mathrm{Mo}_{7} \mathrm{O}_{24}\right]^{4-}$ anions from the first layer by the two terminal oxygen atoms $\mathrm{O}(18)$ and $\mathrm{O}(22)$ of the first polyanion, another polyanion of the first layer is linked to the same organic molecule by using terminal oxygen atom $\mathrm{O}(5)$. The hydrogen bonds are $2.600 \AA$ for $\mathrm{N}(1)-\mathrm{H}(1 \mathrm{C}) \ldots \mathrm{O}(18)$ bond, $2.474 \AA$ for $\mathrm{N}(1)-\mathrm{H}(1 \mathrm{C}) \ldots \mathrm{O}(22)$, and $2.113 \AA$ for $\mathrm{N}(2)-\mathrm{H}(2 \mathrm{C}) \ldots \mathrm{O}(5)$ bond. The polyanion of the second layer shares their terminal oxygen atoms $\mathrm{O}(5)$ and $\mathrm{O}(16)$ with the organic cation via hydrogen bonding interactions. Hydrogen bonds are $2.608 \AA$ and $1.969 \AA$ for $\mathrm{N}(1)-\mathrm{H}(1 \mathrm{~B}) \ldots \mathrm{O}(5)$ and $\mathrm{N}(1)-\mathrm{H}(1 \mathrm{~B}) \ldots \mathrm{O}(16)$ respectively.

The polyoxomolybdate anion is also hydrogen bonded to seven surrounding water molecules. There are two lattice water molecules, kind of which OW(2) and OW(4) are hydrogen-bonded to the same polyanion by sharing two oxygen atoms, and each of the other lattice water molecules, (OW(1), $\mathrm{OW}(3)$, OW(5), OW(6) and OW(7)) are hydrogen bonded to the polyanion by sharing an oxygen atom. Together with the hydrogen bonding between the organic molecules and polyanions the hydrogen bonding interactions with the lattice water molecules give more stability to the compound. 
Fig. 3. Representation of the association mode of two consecutive layers in the structure of $\left(\mathrm{C}_{6} \mathrm{H}_{18} \mathrm{~N}_{2}\right)_{2}$. $\cdot\left[\mathrm{H}_{2} \mathrm{Mo}_{7} \mathrm{O}_{24}\right] \cdot 7 \mathrm{H}_{2} \mathrm{O}$. All lattice water molecules are omitted for clarity

IR and thermal analyses. The IR spectrum was recorded from a $\mathrm{KBr}$ pellet on a Bruker FTIR spectrometer in the range $4000-400 \mathrm{~cm}^{-1}$. The IR spectrum shows characteristic vibrational features similar to the known $\left[\mathrm{Mo}_{7} \mathrm{O}_{24}\right]^{6-}$ anions [41]. The stretching vibrations at $894 \mathrm{~cm}^{-1}$ and $564 \mathrm{~cm}^{-1}$ are attributed to asymmetric $\left(\mathrm{Mo}-\mathrm{O}_{\mathrm{t}}\right)$ and (Mo-O-Mo) vibration modes, respectively, and the peaks $844 \mathrm{~cm}^{-1}, 758 \mathrm{~cm}^{-1}, 669 \mathrm{~cm}^{-1}$ and $627 \mathrm{~cm}^{-1}$ are attributed to other symmetric vibration modes. The absorption bands in the range of $1000-1650 \mathrm{~cm}^{-1}$ are mainly characteristic absorption bands of the protonated hexanediamine

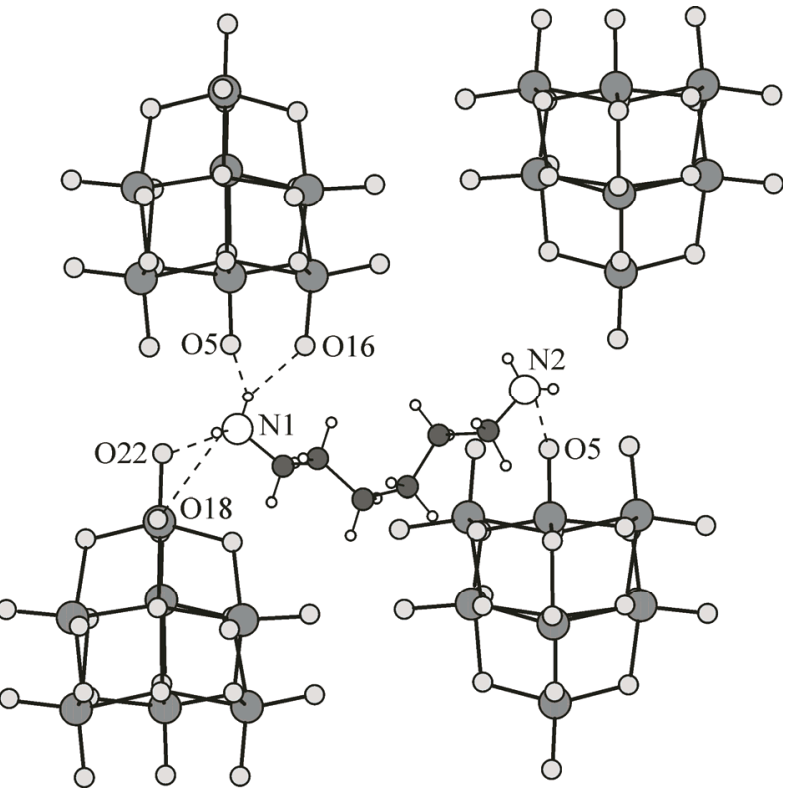
which can be assigned to the bending vibrations of the $\mathrm{C}-\mathrm{H}, \mathrm{N}-\mathrm{H}$ and $\mathrm{C}-\mathrm{C}$ groups. The broad bands at $3356 \mathrm{~cm}^{-1}$ and $1615 \mathrm{~cm}^{-1}$ are associated with the water molecules and a band at $3465 \mathrm{~cm}^{-1}$ is assigned to characteristic vibration modes of the hydroxyl groups of the $\left[\mathrm{H}_{2} \mathrm{Mo}_{7} \mathrm{O}_{24}\right]^{4-}$ anion [36 ].

The thermogravimetric analysis was performed in static air with a heating rate of $5 \% \mathrm{~min}$ in the temperature range from ambient temperature to $550^{\circ} \mathrm{C}$. The thermogravimetric analysis curve shows that the first weight loss is $1.4 \%$ in the temperature range of $100{ }^{\circ} \mathrm{C}$ to $180{ }^{\circ} \mathrm{C}$, corresponding to the loss of one crystal water molecules (cal. $1.3 \%$ ). The second weight loss is $5.2 \%$ from $230{ }^{\circ} \mathrm{C}$ to $320^{\circ} \mathrm{C}$, assigned to the loss of two crystal water molecules (cal. 5.07\%). In the range $380-520{ }^{\circ} \mathrm{C}$, a third weight loss of $19 \%$ is observed corresponding to the loss of four crystal water molecules and one organic molecule (calc. 19.15\%).

Electrochemical behavior. The electrochemical behavior was studied by cyclic voltammetry in $1 \mathrm{M} \mathrm{H}_{2} \mathrm{SO}_{4}$ aqueous solutions at different scan rates. Platinum electrodes were used as the working electrode and counter electrode, the reference electrode was an $\mathrm{Ag} / \mathrm{AgCl}$ electrode. In potential range of $+400 \mathrm{mV}$ to $-800 \mathrm{mV}$ Fig. 4 shows two redox waves corresponding to two consecutive twoelectron processes. The mean peak potentials $E_{1 / 2}=\left(E_{\mathrm{pa}}+E_{\mathrm{pc}}\right) / 2$ negatively shifted to $-760 \mathrm{mV}$ and $-400 \mathrm{mV}$. The two peaks may be attributed to the redox couple $\mathrm{Mo}^{\mathrm{VI} / \mathrm{V}}$ in the polyanion framework.

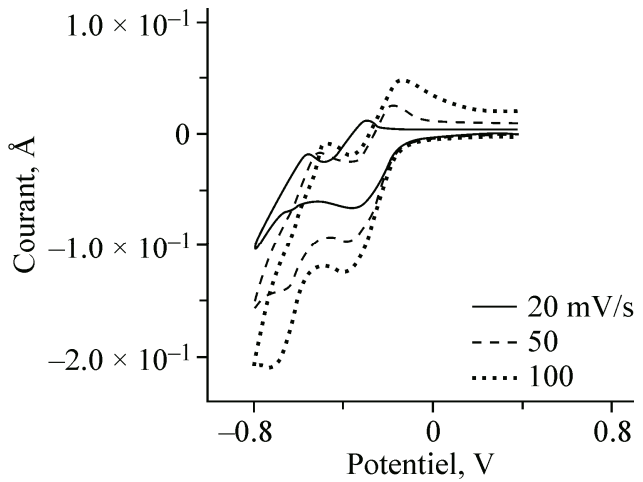

Fig. 4. Cyclic voltammograms of $\left(\mathrm{C}_{6} \mathrm{H}_{18} \mathrm{~N}_{2}\right)_{2}\left[\mathrm{H}_{2} \mathrm{Mo}_{7} \mathrm{O}_{24}\right] \cdot 7 \mathrm{H}_{2} \mathrm{O}$ in $\mathrm{H}_{2} \mathrm{SO}_{4}$ at $\mathrm{Pt}$ electrode and at different scan rates: $20 \mathrm{mV} \cdot \mathrm{s}^{-1}, 50 \mathrm{mV} \cdot \mathrm{s}^{-1}, 100 \mathrm{mV} \cdot \mathrm{s}^{-1}$

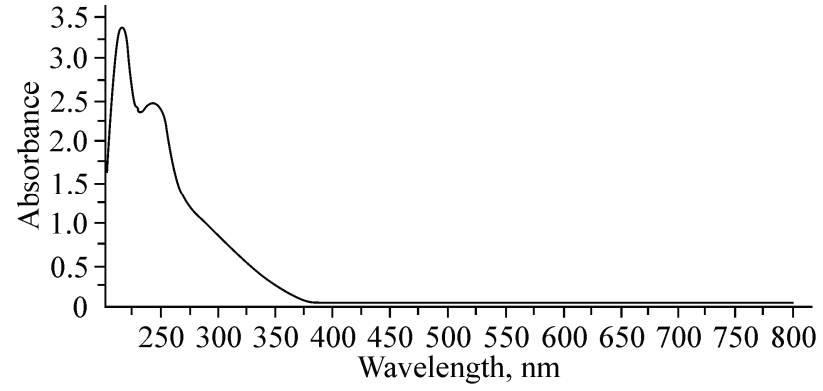

Fig. 5. UV visible absorption spectrum of the compound $\left(\mathrm{C}_{6} \mathrm{H}_{18} \mathrm{~N}_{2}\right)_{2}\left[\mathrm{H}_{2} \mathrm{Mo}_{7} \mathrm{O}_{24}\right] \cdot 7 \mathrm{H}_{2} \mathrm{O}$ 
When the scan rates varied from $20 \mathrm{mV} / \mathrm{s}$ to $100 \mathrm{mV} / \mathrm{s}$, the peak potentials changed with increasing scan rates, the cathodic peak potentials shift towards the negative direction and the correspondding anodic peak potentials - to the positive direction. The peak currents are proportional to the scan rates, which indicates that the redox process on the electrode is surface controlled.

UV-visible absorption spectrum. The UV-visible absorption spectrum was recorded in the $190-800 \mathrm{~nm}$ range in aqueous solution $\left(5 \cdot 10^{-4} \mathrm{M}\right)$. The spectrum (Fig. 5) exhibits two absorptions bands at $217 \mathrm{~nm}$ and $243 \mathrm{~nm}$. The higher energy band can be ascribed to the ligand-to-metal charge transfer (LMCT) from the terminal oxygen to molybdenum, whereas the lower energy band was attributed to the bridging oxygen to molybdenum atom [ $42-44$ ].

\section{CONCLUSIONS}

A novel hybrid organic-inorganic compound has been prepared. The structure has been elucidated by X-ray crystallography, IR, and TG analysis, cyclic voltammetry and UV visible spectrum. The assembly of heptamolybdate, hexanediamine, protons, and water molecules forms a 3D framework via hydrogen bonding interactions. The protonated hexanediamine connects polyanions by the terminal protonated amine groups to form a layer, and these layers are linked together by the organic cations via hydrogen bonds. IR spectrum exhibits the characteristic peaks of the polyanions, the $\mathrm{OH}$ group and the organic amine. In the TG analysis the total weight loss $(25.6 \%)$ is consistent with the calculated value $(25.5 \%)$.

The crystallographic data for the title compound were deposited with the Cambridge Crystallographic Data centre: No. CCDC 887592. These data can be obtained via http//www.ccdc.cam.ac.uk.

\section{REFERENCES}

1. Pope M.T. Heteropoly and Isopoly Oxometalates. - Springer-Verlag, 1983.

2. Wang X., Liu J., Li J., Yang Y., Liu J., Li B., Pope M.T. // J. Inorg. Biochem. - 2003. - 94. - P. 279.

3. Sakamoto T., Pac C. // Tetrahedron Lett. - 2000. - 41. - P. 1009.

4. Uchida S., Hashimoto M., Mizuno N. // Angew. Chem., Int. Ed. Engl. - 2002. - 41. - P. 2814.

5. Cheetham A.K., Rao C.N.R. // Chem. Commun. - 2006. - P. 4780.

6. Dan M., Rao C.N.R. // Angew. Chem., Int. Ed. Engl. - 2006. -45. - P. 281.

7. Coronado E., Gomez-Garcia C.J. // Chem. Rev. - 1998. - 98. - P. 273.

8. Backer L.C.W., Glick D.C. // Chem. Rev. - 1998. - 98. - P. 3.

9. Zhang S.W., Wei Y.G., Yu Q., Shao M.C., Tang Y.Q. // J. Am. Chem. Soc. - 1997. - 119. - P. 6440.

10. Wassermann K., Dickman M.H., Pope M.T. // Angew. Chem., Int. Ed. Engl. - 1997. - 36. - P. 1445.

11. Yan B.B., Xu Y., Bu X.H., Goh N.K., Chia L.S., Stucky G.D. // J. Chem. Soc., Dalton Trans. - 2001. - P. 2009.

12. Johnson B.J.S., Geers S.A., Brennessel W.W., Young V.G. Jr., Stein A. // J. Chem. Soc., Dalton Trans. $-2003 .-$ P. 4678.

13. Li Y.G., Hao N., Wang E.B., Yuan M., Hu C.W., Hu N.H., Jia H.Q. // Inorg. Chem. - 2003. - 42. - P. 2729.

14. Xu Y., Xu J.-Q., Zhang K.-L., Zhang Y., You X.-Z. // J. Chem. Soc., Chem. Commun. - 2000. - 2. - P. 153.

15. Martin C., Lamonier C., Fournier M., Mentré O., Harlé V., Guillaume D., Payen E. // Inorg. Chem. - 2004. - 43. - P. 4636.

16. Reinoso S., Vitoria P., Lezama L., Luque A., Gutiérrez-Zorrilla J.M. // Inorg. Chem. - 2003. - 42. - P. 3709.

17. Yang W.-B., Lu C.-Z., Lin X., Zhuang H.-H. // J. Chem. Soc., Dalton Trans. - 2002. - 14. - P. 2879.

18. $W u$ C.-D., Lu C.Z., Lin X., Huang J.-S. // Inorg. Chem. Commun. - 2002. - 5. - P. 664.

19. Qu X., Xu L., Yang Y., Li F., Guo W., Jia L., Liu X. // Struct. Chem. - 2008. - 19. - P. 801.

20. Evans H.T., Gatehouse B.M., Leverett P. // J. Chem. Soc., Dalton Trans. - 1975. - P. 505.

21. Sjoebom K., Hedman B. // Acta Chem. Scand. - 1973. - 27. - P. 3673.

22. Khazheeva Z.I., Khaikina E.G., Khal'baeva K.M., Shibanova T.A., Molchanov V.N., Simonov V.I. // Kristallografiya. - 2000. - 45. - P. 996.

23. Khazheeva Z.I., Khaikina E.G., Khal'baeva K.M., Shibanova T.A., Molchanov V.N., Simonov V.I. // Crystallogr. Rep. - 2000. - 45. - P. 916.

24. Kortz U., Pope M.T. // Acta Crystallogr., Sect. C. - 1995. - 51. - P. 1717.

25. Wutkowski A., Srinivasan B.R., Naik A., Schütt R.C., Näther C., Bensch W. // Eur. J. Inorg. Chem. - 2011. - P. 2254. 
26. Pavani K., Ramanan A. // Eur. J. Inorg. Chem. - 2005. - P. 3080.

27. Li T., Lu J., Gao S., Cao R. // Inorg. Chem. Commun. - 2007. - 10. - P. 1342.

28. Roman P., Gutierrez-Zorrilla J.M., Luque A., Martinez-Ripoll M. // J. Crystallogr. Spectrosc. Res. - 1988. - 18. - P. 117.

29. Arumuganathan T., Srinivasarao A., Kumar T.V., Das S.K. // J. Chem. Sci. - 2008. - 120. - P. 95.

30. Gili P., Lorenzo-Luis P.A., Mederos A., Arrieta J.M., Germain G., Castineiras A., Carballo R. // Inorg. Chim. Acta. - 1999. - 295. - P. 106.

31. Yamase T. // J. Chem. Soc., Dalton Trans. - 1991. - P. 3055.

32. Sheldrick G.M. SHELXS97, Program for Crystal Structure Solution. - Germany: University of Gottingen, 1997.

33. Sheldrick G.M. SHELXL97, Program for Crystal Structure Refinement. - Germany: University of Gottingen, 1997.

34. Farrugia L.J. // J. Appl. Crystallogr. - 1999. - 32. - P. 837.

35. Brown I.D., Altermatt D. // Acta Crystallogr. - 1985. - B 41. - P. 244.

36. Kuei-Fang H., Sue-Lein W. // Inorg. Chem. - 1997. - 36. - P. 3049.

37. Roman P., Aranzabe A., Luque A., Gutierrez-Zorrilla J.M., Martinez-Ripoll M. // J. Chem. Soc., Dalton Trans. - 1995. - P. 2225.

38. Strukan N., Cindrid M., Kamenar B. // Polyhedron. - 1997. - 16. - P. 629.

39. Fa-Nian S., Filipe A., Almeida P., Penka I., Joao R., Vitor S. // J. Solid State Chem. - 2006. - 179. - P. 1497.

40. Cappare M.V., Goodgame D.M., Hayman P.B., Skapski A.C. // J. Chem. Soc. Chem. Commun. - 1986. - P. 776.

41. Evans H.T., Gatehouse B.M., Leverett P. // J. Chem. Soc., Dalton Trans. - 1975. - P. 505.

42. Yamase T. // Chem. Rev. - 1998. - 98. - P. 307.

43. Zhang X.M., Shen B.Z., You X.Z., Fun H.K. // Polyhedron. - 1997. - 16. - P. 95.

44. Gong Y., Hu C., Li H., Tang W., Huang K., Hou W. // J. Mol. Struct. - 2006. - 784. - P. 228 - 238. 